\section{0 years of immunization in Mozambique: a narrative review of literature, accomplishments, and perspectives}

\author{
Quarenta anos de imunização em Moçambique: \\ uma revisão narrativa da literatura, avanços e \\ perspectivas
}

\section{0 años de inmunización en Mozambique: una revisión narrativa de la literatura, logros y perspectivas}

\begin{abstract}
In Mozambique, the Expanded Program on Immunization (EPI) was implemented in 1979 with the objective of reducing child mortality and morbidity through the provision of immunization services. This study aims to describe the characteristics of the EPI and review the available information related to immunization service in Mozambique, its accomplishments and perspectives. A narrative review of the literature was carried out and the electronic databases accessed were VHL, Google Scholar, and PubMed between 1979 and 2019, using descriptors related to the theme. A total of 28 articles and other relevant sources have been consulted for the review. The national immunization coverage in Mozambique between 1997 (47\%) and 2015 (66\%) improved 19 percentual points; also immunization coverage of children under 12 months has increased from 44.3\% (1997) to 57\% (2015). The 2015 survey showed that out of the 11 provinces, only the southern and Cabo Delgado province could reach the $80 \%$ recommended goal at the provincial level. Zambézia, Nampula, and Tete provinces have been reporting low coverage over the years and Cabo Delgado presents coverage oscillation. The BCG, DPT3, Polio3, and measles have reached $80 \%$ of coverage goal from 1997 to 2015. Our analysis have shown important improvements in national immunization, characterized by an overall increase in the national and provincial coverage and a decrease in the number of children that did not receive any vaccine. Despite these improvements, some provinces have lower coverages than expected and it is necessary to understand the determinants of dropout in children to retain them and provide timely and full immunization.
\end{abstract}

Marta Cassocera 1,2 Assucênio Chissaque 1,2 Maria R. O. Martins 2 Nilsa de Deus 1

doi: $10.1590 / 0102-311 \times 00038320$

\author{
orrespondence \\ N. Deus \\ Instituto Nacional de Saúde. \\ EN1, Bairro da Vila-Parcela no 3943, Marracuene, Província de \\ Maputo, Moçambique. \\ ndeus1@yahoo.com \\ 1 Instituto Nacional de Saúde, Província de Maputo, \\ Moçambique. \\ 2 Instituto de Higiene e Medicina Tropical, Universidade NOVA \\ de Lisboa, Lisboa, Portugal.
}




\section{Introduction}

Children immunization is considered one of the most cost-effective strategies to reduce morbidity and mortality in children worldwide 1 . Every year, up to three million lives are saved thanks to immunization programs 1,2 .

In 1974, the World Health Organization (WHO) established the Expanded Program on Immunization (EPI) to ensure that all children had access to routinely recommended vaccines 3 . In response to challenges of the EPI worldwide, in 2006 the WHO and the United Nations Children's Fund (UNICEF) developed the Global Immunization Vision and Strategy (GIVS) plan, a 10-year plan guiding countries to immunize as many people as possible against vaccine-preventable diseases, to introduce new vaccines and technologies and to provide other important interventions 4.

Immunization coverage is one of the main performance indicators used to measure the performance of an immunization program, and it is defined as the proportion of people from a certain population and time that received the last dose of vaccines to specific diseases. Knowing the immunization coverage is necessary to divide the number of vaccinated people for the total number of the population eligible for vaccination 5,6. It was expected that in 2010 all the countries should have reached a national coverage of $90 \%$ and $80 \%$ in districts or administrative equivalent 4 . After GIVS ended in 2010, in May 2012 the World Health Assembly (WHA) adopted the Global Vaccine Action Plan (GVAP) 2011-2020 for the decade aiming to prevent deaths by 2020 through more equitable access to existing vaccines for all communities, until 2013 2. This strategy was endorsed by 194 member states of the WHA with the following goal: all countries that reach more than $90 \%$ of national coverage for all vaccines in the country's routine immunization schedule by 2020 will achieve a world free of poliomyelitis; meet vaccination coverage targets in every region, country, and community; exceed the millennium development goal four targets for reducing child mortality; meet global and regional elimination targets; develop and introduce new and improved vaccines and technologies 3 . The following indicators are used to monitor the GVAP: national, district and DTP3 (diphtheria-tetanuspertussis) vaccination coverage, dropout (proportion of children who started but did not complete immunization series), the third dose of polio vaccine and the first dose of measles-containing vaccine (MCV1) coverage 2 .

The vaccination coverage in African countries has increased in the last decades, decreasing children's morbidity and mortality due to vaccines-preventable diseases. However, coverage rates, both national and vaccine-related, remain far from the recommended goal defined by the GVAP which still contributes to child morbidity and mortality across the African countries 7 .

The US Centers for Disease Control and Prevention (CDC) and the WHO evaluated the global vaccine coverage by WHO regions to monitor the GVAP. They observed that African region presents the worst scenarios for the main indicators; for example, dropout is higher in this region (11\%); DTP3 has the lowest coverage (74\%); among the 19.5 million children worldwide who did not receive DTP3 doses during the first year of life, 11.8 million are divided into 10 countries, five of them African (Nigeria, Ethiopia, Democratic Republic of Congo, Angola, and South Africa) 8.

In Mozambique, the EPI was implemented in 1979 with the objective of reducing child mortality and morbidity through the provision of immunization services at all levels. Since then, several vaccines were introduced in the national immunization schedule supported by WHO, UNICEF, and Global Alliance for Vaccine Initiative (GAVI).

Between 1997 and 2015, five community surveys were carried out in the country to measure the main health indicators, including immunization coverage at national and provincial level 9,10,11,12,13. These surveys are powerful because mothers are interviewed in the community and asked for the children's immunization cards which are copied to record the vaccination dates. Those mothers who did not present vaccination cards, verbal questions about vaccination and number of doses were recorded. The surveys are also important because they enable the assessment of equity in the provision of routine immunization services and to analyze how coverage behaves concerning the different health determinants such as sex, birth order, area of residence, mother's education level, wealth quintile, and others 14. Furthermore, it allows monitoring national and provincial coverage over the years, determining which vaccines are best performing and the country's ability to comply with the GVAP. An analysis of this scale can be useful for policymakers to design strategies to improve the perfor- 
mance of national immunization program in a sustained manner, thus increasing vaccine-preventable diseases protection. Thus, the main objective of this manuscript is to review the available information related to vaccination in Mozambique since EPI implementation and to describe its characteristics, accomplishments in the past four decades, and the perspectives for the next years.

\section{Methodology}

A narrative review of the literature was carried out. The inclusion criteria for resources used was: (i) date of publication between January 1979 to December 2019; (ii) articles, reports, manuals, and official websites published in English or Portuguese; and (iii) articles, reports, manuals, and official websites with relevant information regarding immunization services/coverage and its determinants in Mozambique and Africa. Isolated (child; immunization; vaccine coverage; vaccine; Mozambique) and combined (immunization in Mozambique; vaccine coverage in Mozambique; child immunization in Mozambique; immunization coverage and Africa; EPI and Mozambique) keywords terms were used to selection, according to the most relevant content to the paper.

We used two types of tools: (i) electronic databases namely Google Scholar, PubMed, and VHL and (ii) reports, websites and manuals from official sources. Two reviewers screened the titles and abstracts and selected original articles and other relevant sources.

\section{Results and discussion}

After removing the duplicate articles and those articles that did not meet the inclusion criteria, a total of 28 articles and 19 reports, 13 websites and two manuals have been selected for this analysis, totaling 62 information sources (Supplementary Material. http://cadernos.ensp.fiocruz.br/static/arquivo/ suppl-csp-0383-20_5726.pdf).

Four main themes emerged from this revision:

(1) The characteristics of EPI and vaccination policies in Mozambique had its information derived from research articles, publications on organizations websites, and official documents from national EPI, and WHO;

(2) Operationalization of the immunization service, which information was derived from research articles and official documents from GAVI;

(3) Immunization coverage estimates by surveys, derived from national and international surveys and official documents from organizations working on immunization; and

(4) Monitoring of vaccine-preventable diseases, which information derived from research articles, publications on organization's web pages and official documents.

\section{Characteristics of EPI and immunization policies in Mozambique}

In Mozambique, the EPI completed its 40th anniversary of implementation in 2019. EPI has committed itself to reduce child mortality and morbidity with immunization services at all levels, to achieve the long-term goal of reducing vaccine-preventable diseases 15,16. Before its establishment, from 1976 to 1979, Mozambique carried out the first National Vaccination Campaign, where vaccines against smallpox, measles, tuberculosis, and tetanus (for women in childbearing age) were provided, which has shown remarkable health gains over the years, by the lives saved with the administration of such vaccines. Therefore, in 1980, immunization became part of routine child health services 16,17 by offering vaccines against tuberculosis (BCG), poliomyelitis (OPV), measles, and diphtheria-pertussistetanus (DTP). This service was implemented in rural and urban areas and it was expanded to larger cities in 198317.

A few years later, cluster sample surveys have shown that the immunization coverage of children aged 12-23 months completely vaccinated in Maputo city, increased from an average of 38\% to $84 \%$ between 1982 and 1986, respectively. The coverage of tetanus toxoid (TT2) for mothers also increased from $42 \%$ (1982) to $91 \%$ (1983) and it had a slight decrease to $87 \%$ three years later (1986). The other 
four cities (Inhambane, Beira, Quelimane, and Tete) were also surveyed in 1985 and 1987 and the data presented an increasing average from $36 \%$ to $55 \%$ respectively, but on the other hand the coverage of TT2 decreased from 70\% to 67\% in the same period. Despite its significant accomplishments, thousands of children were still getting sick and dying every year from vaccine-preventable diseases 18 .

The 80-80 goals set in 2000 by the GAVI and the WHO, which objectives were reaching: (i) $\geq 80 \%$ of coverage of DTP3; (ii) in every district of more than $80 \%$ of developing countries by 2005 , culminating with the creation of the Reaching Every District (RED) strategy in 2002 19. With the start of the GAVI support in the country in 2001, gradually, new vaccines (hepatitis B, followed by Haemophilus influenzae type B (Hib) in 2008, pneumococcal conjugate vaccine (PCV) in 2013, and rotavirus, injected polio, and measles second dose in 2015 were included in the national immunization schedule 18,20 (Figure 1). In 2014, the country conducted a demo pilot for HPV vaccine for pre-teen girls in three districts, as a preparation for a national scale vaccination, but this vaccine is not yet included in the country schedule 18. In September 2019, the schedule was updated, with the addition of the measlesrubella vaccine (Box 1).

In 2008, strategies such as RED and National Health Week - where several immunization activities (vaccination in primary schools, health services to child and women in childbearing age, vaccine education, and mobilization) are carried out -, were implemented in order to increase coverage and reduce inequities related to the provision of vaccination services 20,21. Moreover, community health workers (CHW) have supported many health programs, including EPI by extending its services to the most vulnerable and disadvantaged population, thus achieving more satisfactory public health

\section{Figure 1}

Mozambican Expanded Program on Immunization (EPI) most relevant events from 1979 to 2019.

1979

Implementation of EPI in Mozambique
2001-2008

2001 - GAVI support in the country; 2006 - Implementation of measles and rubella surveillance; 2008 - Vaccines introduced: hepatitis B antigen followed by Haemophilus influenzae type $B(\mathrm{Hib})$

1980-1997

1980 - Immunization became a routine child health service: smallpox, measles, tuberculosis and tetanus; 1983 - Immunization programs were implemented in rural and urban areas; 1997 - Implementation of polio surveillance

\section{5}

EPI introduced rotavirus, injected polio and measles second dose vaccines

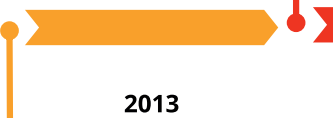

EPI introduced pneumococcal conjugate vaccine (PCV); Implementation of rotavirus surveillance; Implementation of meningitis surveillance

\section{9}

The schedule vaccination was updated with addition of measles-rubella vaccine

GAVI: Global Alliance for Vaccine Initiative. 
Box 1

Current Mozambican immunization schedule, September 2019.

\begin{tabular}{|l|c|}
\hline Vaccine & Schedule \\
\hline BCG (Bacillus Calmette-Guérin) & At birth \\
\hline Polio (oral polio vaccine) & At birth, 2nd month, 3rd month, 4th month \\
\hline $\begin{array}{l}\text { DTP/HepB/Hib (diphtheria, tetanus texoid, pertussis, } \\
\text { Haemophilus influenzae type B and hepatitis B) }\end{array}$ & $2^{\text {nd }}$ month, 3rd month, 4th month \\
\hline Rotavirus & 2nd month, 3rd month $^{\text {2nd } \text { month, 4th month, 9th month }}$ \\
\hline PCV (pneumococal conjugate vaccine) & 4th month \\
\hline IPV (injected polio vaccine) & 9th month, 18th month \\
\hline Measles and rubella & 6th month, 12th month, every six month until 59 \\
Vitamin A & 12th months \\
\hline Deworming & \\
\hline
\end{tabular}

goals 22,23. The number of CHW in Mozambique has increased significantly from 170 (2010) to 3,051 (2017), which may have reduced the geographical inequities as distances between health services and communities were shortened 24 .

\section{Operationalization of the immunization service: financing and stakeholders; cold chain and routine data flow}

The Mozambican EPI financing support has been provided by several stakeholders namely: the Government of Mozambique, GAVI, Health Sector Common Fund (Prosaúde), the United States Agency for International Development (USAID), WHO, UNICEF, Bill \& Melinda Gates Foundation (BMGF), Canadian International Development Agency (CIDA) 25 and other civil society organizations such as Foundation for Community Development (FDC) and Village reach 24. The GAVI and the Government of Mozambique (by the Mozambican Ministry of Health) are the major funders of EPI providing 64\% (USD 234,743,835) and 23\% (USD 20,638,423) of the budget respectively 16 . Out of $64 \%$ of the budget provided by GAVI, $63 \%$ was for expenses related to new vaccine support (NVS) and the remaining $1 \%$ for ISS. Out of the $23 \%$ of the budget provided by the Government of Mozambique, $18 \%$ were for general routine costs and $5 \%$ for co-financing of DTP and PCV vaccine 16 . The 2016 GAVI Full Country Evaluation reported that, the Government of Mozambique has annually provided funds for the procurement of traditional vaccines and its distribution by the national airline company 25. The Government of Mozambique expenditure on routine immunization made a satisfactory increment of 79\% between 2011 (USD 3.4 million) and 2013 (USD 6.1 million), which clearly demonstrates the commitment of the government and its partners in improving the program.

According to the Comprehensive Multi-Year Plan, the total EPI expenditure in Mozambique for the period of 2014-2019 was estimated at USD 351.3 million (excluding shared costs of USD 6.9 million), an average of USD 68.9 million annually, and the routine immunization (national health weeks and outreach services excluded) uses $88 \%$ of the budget 16 .

The GAVI has been in the funding frontline of the immunization services of many low and middle-income countries 26, including Mozambique, playing an important role in the reduction of deaths by preventable diseases in young children.

Countries can apply for four types of support to help them address coverage inequity: (i) vaccine introduction and campaigns; (ii) health system strengthening; (iii) cold chain equipment, and (iv) technical assistance 27 . 
The GAVI support in Mozambique began in 2001, as it has been in the list of eligible countries from which support is provided through request based on their national vision, planning, and financial cycles. The support has started by providing ISS and shortly thereafter by supporting the introduction of vaccines such as tetra DTP-HepB (2001-2007), pentavalent vaccine (2009-2019), PCV (2013-2019), HPV demonstration (2014), measles second dose (2015-2017), IPV (2015-2019), and rotavirus (2015-2019) 25.

According to the 2016 GAVI Full Country Evaluation, during 2013, 2014 and 2015, the contribution of GAVI to the EPI total budget was 31\%, 71\%, and 75\% respectively, and the largest funding was observed in 2015, with the first disbursement of the health system strengthening support and the introduction of new vaccines namely rotavirus, IPV, and measles second dose 25 . For the period, from 2000 to 2019, the GAVI has made a disbursement of USD 259,723,474 for all types of support. Particularly, GAVI has committed to support with about USD 5,128,062 the cold chain equipment optimization platform to from 2001-2023, more than $11 \%$ of the approved budget 28 . According to the EPI inventory carried out in $2003,88 \%(1,449 / 1,638)$ of the total refrigerators were functional, but a national review from 2006 showed that significant investment to update the cold chain equipment was necessary. Vaccine poor conditions, temperatures not being recorded as specified, inadequate stock records were some of the weaknesses at the health facility and district level and they had to be improved 15. Data from the Mozambican Ministry of Health reports that, in an assessment carried out in 2012, the cold chain did not have enough capacity to introduce new vaccines, such as rotavirus and measles second dose to the system; and out of the 11 provinces, only eight could accommodate the vaccines planned to be introduced ${ }^{29}$. A national cold chain plan for 2014-2018 referred to the need for expanding the cold chain to accommodate the new vaccines to the EPI. The plan also contemplates several reforms to the cold chain system, since the creation of regional vaccine depots (to Center and North region), replacement of old/worn-out equipment, acquisition of temperature monitors to all levels of the system and also training of cold chain maintenance technicians at provincial and district level 29. The introduction of new vaccines in the immunization schedule in 2015 demonstrates the adoption of the plan recommendations with the intervention of different stakeholders.

Since GAVI support started in the country, the vaccine coverage has increased over time as surveys have demonstrated. Although this support plays an important role, the waiting time associated with financing cycles, from the moment of the support request until its implementation, may lead to changes in EPI priorities and also influence the outcome of immunization coverage 26.

The support provided by GAVI can be masked by country-specific issues that do not help to meet expected coverage goals. Until 2018, the nurse/midwifery staff ratio in the country was 0.7 per 1,000 habitants, a low ratio when compared to Zimbabwe (1.9), and Zambia (1.3) 30. These are the main health personnel in the front line providing women and child health care in low- and middleincome countries, which may suggest a weakness in the availability of human resources to support the provision of vaccination services. Mozambique is a country located on the cost of the Indian Ocean, vulnerable to climatic effects and natural disasters (rains, cyclones, droughts), and these may substantially contribute to the destruction of access roads, people migration, and consequent interruption of healthcare services, including immunization. According to the Southern African Development Community (SADC) Statistical Yearbook from 2015, the density of the Mozambican population was estimated at 32 people per square kilometer $\left(\mathrm{km}^{2}\right)$, which is lower than Zimbabwe (36 people/ $\mathrm{km}^{2}$ ) and Tanzania (55 people $/ \mathrm{km}^{2}$ ), showing a greater dispersion of communities and the need of extra effort to reach people, mostly in restricted areas. Although immunization services are available in $90 \%$ of the health units, the National Inventory to the health facilities shows that the availability of vaccines for children was found in only $65 \%$ of them. The same inventory has shown that all basic vaccines were under stock rupture in the last three months before the survey, with pneumococcal and poliovirus vaccine being the most ruptured 31 .

To what concerns the provision of immunization service, this is part of the primary health services and it is provided by health facilities and outreach services. The collection of routine data starts at this point and it is where the estimates of administrative coverage from the Mozambican Ministry 
of Health is originated, which are collected firstly from health facilities, districts and then to central level 32 . After a child is vaccinated in the health facility or by outreach service, data of all received vaccines are recorded into specific tally sheets (A01), and for the tetanus toxoid vaccine a different one (A02) is also filled out. These data are collected monthly in a health facility and outreach tally sheet (A03) and then all data from several facilities are aggregated at the district level in a specific district tally sheet (A04). Then, the district sends the data monthly to the provincial level, and after entering it in the database, these are sent to national level quarterly 33.

In 2005, a study conducted at a district level aimed to evaluate data quality and record-keeping practices from routine data was published. It showed differences for all types of vaccine between health facilities with the tally sheets reports, higher values to health facilities when compared to the original tally sheets. The study was conducted in seven health facilities of which only one reported consistent data for all vaccines excepting BCG, and another facility reported underestimated data for all vaccines when compared to the tally sheets. Comparing health facilities and tally sheets, an average increase of $7 \%$ for all vaccines were reported. Also, some differences related to the number of vaccines were found between health facilities and district reports 33 .

Furthermore, single monthly analyzes of health facilities showed some data reports on immunized children in months that not even one children record in the immunization tally sheets was made, reasons reported for these inconsistencies were threats regarding salary cuts in case of low performance of health works. On the other hand, immunization services were performed but no reports to the district level were made ${ }^{33}$. Although supervision visits in health facilities occur months prior to the study, these visits were primarily focused on data-quality assessment for outpatients and not directed to data consistency between facilities reports and tally sheet records. A data quality audit conducted in 2002 and a data quality self-assessment conducted in several districts by provinces between 20102012 showed that there is a continued poor data management of immunization routine data. Additionally, over and underreporting remains a problem in all levels 16,29. Data accuracy, completeness, timeless report, inconsistency between different levels, poor filling of the vaccination registration are some of the challenges in the immunization services and they exist for many years.

\section{Immunization coverage estimates by surveys}

\section{- National, provincial and vaccine coverage}

National Demographic Health Surveys (DHS) show that immunization coverage is increasing slowly. In 1997 , the national estimate of immunization coverage was $47 \%$, with a great increase to $63 \%$ in 2003. Then, in 2008 the coverage dropped to 60\%, and it increased to 64\% and 66\% in 2011 and 2015 respectively 9,10,11,12,13 (Figure 2). However, the absence of surveys between 2016 and 2019 does not allow data analysis for the last four years.

The Mozambican's immunization coverage of children aged 12-23 months in the last survey is higher when compared to Angola's (DHS 2015-2016) and South Africa's (DHS 2016) with 31\% and 61\% respectively 34,35. On the other hand, Zambia (DHS 2018) and Tanzania (DHS 2015-2016) reported coverage of 75\%, also Zimbabwe (DHS 2015) and Malawi (DHS 2015-2016) reported both a coverage of $76 \%$ when compared to Mozambique 36,37 .

Regarding the provincial level, Maputo city and its province have been constantly reporting higher immunization coverage in all surveys when compared to other provinces. Therefore, Zambézia, Nampula, and Tete provinces presented constantly lower coverages in all surveys, but Nampula and Zambézia are the most densely provinces 9,10,11,12,13.

While most provinces, maintain a stable position regarding both increase or decrease of coverage, Cabo Delgado coverage oscillates over time (Table 1) 9,10,11,12,13. Among African countries, Zimbabwe reported coverage of $91 \%$ at the provincial level, the highest value when compared to Mozambique, Angola, Zambia, and South Africa. These value possibly shows a geographical inequity in the provision of immunization services $34,35,37,38$.

The GVAP on the goal set to 2015-2020, determined (a) polio eradication after 2014, (b) by 2015 a $90 \%$ of children protected with DTP3 and Mozambique reached in 2015 the goal of DTP3. Regarding poliovirus, the country was able to interrupt the circulation of wild poliovirus in 2016 39, although 
Figure 2

Trends of national and vaccine coverage between 1997 and 2015 surveys. Mozambique.

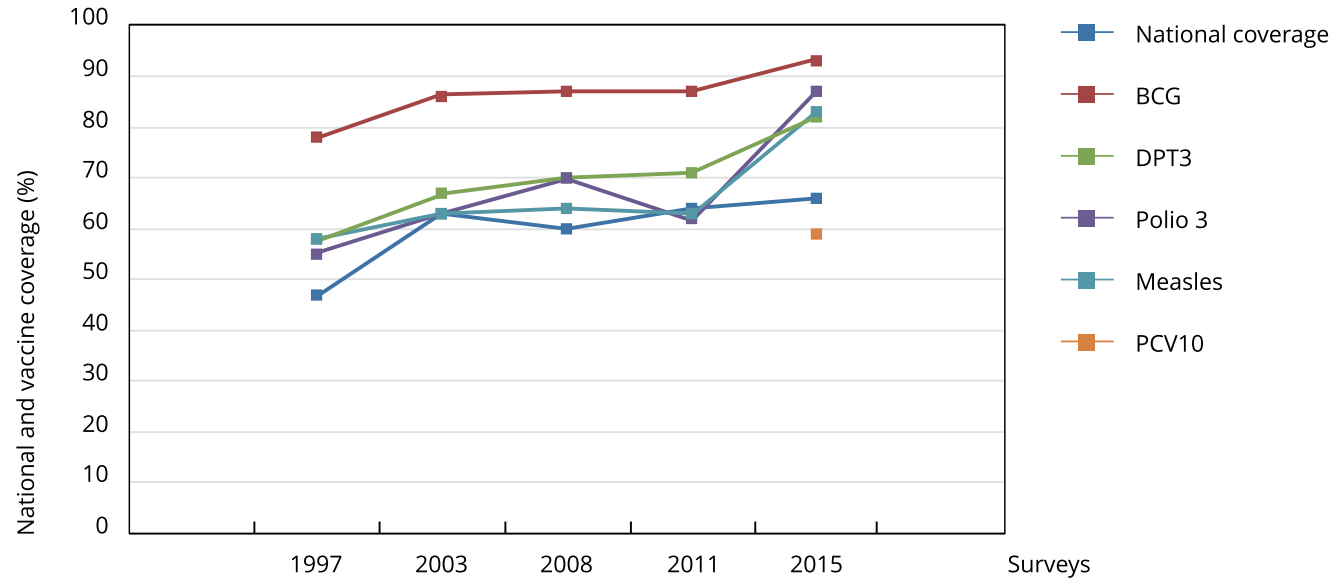

DTP3: diphtheria pertussis-tetanus (DTP3); PCV10: 10-valent pneumococcal conjugate vaccine.

Table 1

Immunization coverage by Mozambican provinces from 1997 to 2015.

\begin{tabular}{|c|c|c|c|c|c|}
\hline \multirow[t]{2}{*}{ Province } & \multicolumn{5}{|c|}{ Surveys } \\
\hline & 1997 & 2003 & 2008 & 2011 & 2015 \\
\hline Cabo Delgado & 25.4 & 57.9 & 70.5 & 58.5 & 86.2 \\
\hline Niassa & 48.2 & 46.6 & 56.4 & 77.2 & 78.0 \\
\hline Nampula & 34.4 & 53.9 & 51.4 & 66.3 & 52.1 \\
\hline Zambézia & 23.2 & 44.7 & 47.6 & 47.3 & 49.9 \\
\hline Tete & 48.0 & 55.0 & 34.2 & 58.0 & 53.1 \\
\hline Manica & 46.5 & 61.6 & 58.3 & 64.6 & 65.8 \\
\hline Sofala & 49.6 & 63.9 & 72.3 & 78.4 & 69.1 \\
\hline Inhambane & 71.7 & 90.6 & 79.8 & 64.7 & 81.0 \\
\hline Gaza & 63.0 & 82.3 & 73.9 & 76.3 & 84.8 \\
\hline Maputo province & 61.9 & 92.5 & 81.9 & 87.9 & 82.8 \\
\hline Maputo city & 82.0 & 91.3 & 81.9 & 76.7 & 87.1 \\
\hline
\end{tabular}

polio's outbreaks derived to polio vaccine (type one and type two) are still reported through the acute flaccid paralysis (AFP) surveillance.

The surveys evaluated information regarding specific vaccine among children aged between 12 and 23 months, as this group is considered to have had all essential vaccines (BCG, DTP3, Polio 3, and Measles). Among all essential vaccines BCG has shown the highest coverage and a significant increase from 1997 to 2015 with $78 \%$ and $93 \%$ respectively. The highest coverage in this vaccine can be justified as it is administered in newborns at birth in the health facility. Polio 3 (55\% and $87 \%$ ) and DTP3 (58\% and $82 \%$ ) vaccines present high and almost similar coverages as well, which can be justified by their being administered at the same time. The measles vaccine shows a great increase from 1997 (54.7\%) to 2015 (82.7\%). The PCV10 vaccine was introduced in 2013 and the IMASIDA's survey could estimate a lower coverage of $75.7 \%$, for the first time in children aged 12 to 23 months (Figure 2). 
Annual estimates from WHO/UNICEF and official estimates from the Mozambican Ministry of Health enables the determination of specific vaccine coverage from 2016 to 2017 and their coverage reports presents considerable differences. Estimates from the Ministry of Health are very high compared to WHO/UNICEF estimates, and the major difference can be verified in data from 2017, in which most vaccines reached the coverage of $99 \%$ reported by the Ministry of Health compared to the range between $80 \%$ and $96 \%$ reported by WHO/UNICEF.

Mozambique did not achieve the goal of $90 \%$ national coverage in 18 years from the first survey until the last (1997-2015), the national highest coverage reported so far is 66\% from 2015 survey 13 as recommended by GIVS 4. Regarding provincial level, the last survey published in 2015, showed that only Southern provinces (Maputo province, Maputo city, Inhambane, and Gaza) and the Northern province of Cabo Delgado succeed to reach the $80 \%$ coverage goal 9,10,11,12,13. This shows inequities in the provision of health services in Mozambique and considerable geographical variation. Complementary researches are necessary to better understand this phenomenon.

\section{- Immunization coverage in children under 12 months}

The immunization schedule indicates that children aged under 12 months must have received all basic vaccines (BCG, Polio 3, DTP3, and measles) however, surveys data show lower coverage in almost two decades, from 44.3\% in 1997 to 57\% in 2015 9,10,11,12,13. Under the SADC countries, the Mozambican immunization coverage in this group is lower when compared to South Africa (58\%), Lesotho (60\%), Namibia (63\%), Tanzania (68\%), Zimbabwe (69\%), Malawi (70\%), and Eswatini (74\%) in their last DHS, but higher when compared to Angola (28\%), Democratic Republic of Congo (41\%), and Madagascar (55\%) $34,36,38,40,41,42,43$. This data provide two important messages: (i) the optimal coverage is still a challenge in Mozambique and the country is far of reach the global indicators and (ii) EPI must improve the services and access to vaccination at all levels and also focus in younger infants.

\section{- Vaccine dropout rate}

Vaccine dropout is the proportion of children who started vaccination but did not complete it, between the first and the last dose, mainly measured by estimating the coverage percentage of DTP1 minus DTP3/DPT1 coverage*100 44 and this indicator allows the evaluation of EPI performance. The rate of vaccination dropout in African countries is $11 \%$, which is above the GVAP target $(\leq 10 \%)$ when compared to the Western Pacific region with $0.4 \%$ estimated in 2016 with DTP3 vaccine 8 . In Mozambique, the rate of vaccine dropout of DTP3 and Polio 3 vaccines is still high. However, between 1997 and 2015 the dropout of DTP3 decreased from 21\% to 8.4\%, and Polio 3 also reduced from 28\% to $18.5 \%$ respectively. Angola's DHS (2015-2106) has shown that the dropout rate for the same vaccines is $29 \%$ and $26 \%$, which is beyond the GVAP goal. Whereas in Zimbabwe 2015 DHS, the dropout rate for DTP3 and Polio 3 was 7\% and 8\%, respectively. An analysis conducted in 15 West African countries from the Economic Community of West African States (ECOWAS), using the WHO and UNICEF estimates of national immunization coverage from 2000 to 2017, showed that the average dropout reduced from $16.4 \%$ to $7.4 \%$ in 17 years, showing stability of the GVAP target for nine years (since 2008). The same study has shown that some characteristics such as residing in urban areas, people living in regions with the highest coverage, the wealthiest quintile, mothers with a secondary education level or higher, are relevant to reduce dropouts values 45 .

In Ghana (Techiman), a study where the dropout rate was determined by using the BCG (as the first vaccine in their EPI schedule) and Measles (as the last vaccine), the dropout of BCG-Measles was $5.6 \%$ 44. Also, children of married mother, profess to the Christian religion were presented as less likely to dropout. Nevertheless, male children and not presenting an immunization card were related to the abandonment of the immunization schedule in the same study 44 .

The decrease of Mozambique dropout rate over the years is a relevant demonstration that significant progress of EPI services is occurring, however, reasons to vaccine dropout are poorly understood and measures need to be taken to understand why polio vaccine has a higher dropout rate 9,10,11,12,13. 


\section{- Determinants of immunization coverage}

Immunization coverage in Mozambique has been increasing slowly over the past decades and several determinants may be associated with lower national and provincial coverage. Surveys data have shown that: (i) mothers with poor education level, (i) lowest wealth quintile, and (iii) residing in urban areas, are the main determinants to incomplete immunization status 9,10,11,12,13. Regarding the area of residence, the urban coverage has shown to be higher when compared to the rural coverage in all surveys. In 1997 the difference between urban and rural coverage was 85\% and 36.4\% respectively, later in 2015 the significant difference between urban (77.9\%) and rural (67.1\%) was still observed. However, the vaccination coverage in rural areas tends to increase compared to the urban which is linear in different surveys, which can be explained by the high growth rate of the urban population in the country with $3.3 \%$ per year 46 .

In 1997 the immunization coverage was $89.7 \%$ for mothers who completed secondary/higher education level when compared to mothers who did not attend to school with $30.6 \%$. In the last survey of 2015 this inequity is still verified in these two groups, with $84.7 \%$ to children from mothers with higher education levels and $52.5 \%$ for those whose mothers did not attend school. Wealth quintile was not measured in 1997, however in all other surveys a higher immunization coverage is presented for children from households with the highest quintile (Table 2). In Africa, many determinants have been associated with incomplete immunization status: in Ghana being a divorced mother and having part-time work were positively associated with incomplete immunization 47 . In Cameron, a survey conducted in the West region showed that mothers' lower use of antenatal visits, being $\geq 3$ born child, younger mothers, parental poor exposure to information about immunization was significantly associated with incomplete immunization 48. A secondary analysis from Senegal DHS has shown that mothers who could show immunization cards, complete secondary/higher education level, attend to at least four antenatal visits, and childbirth in a health unit were associated with full immunization status 49 . In Ethiopia, being a father with secondary school, having a higher family income, an average walking time of one hour to vaccination place, discussing immunization with health workers and mothers with knowledge of immunization was also associated with complete immunization status 50 . Studies to identify determinants of immunization in Mozambique are scarce, the few existing have been carried out in the Southern provinces of the country. These indicate that the poor access to vaccination places, mother's low education level, childbirth at home or outside the health unit, and area of residence were the reasons for incomplete vaccination 51,52 . Thus, the epidemiology of children with incomplete vaccination and its determinants in African countries can be related to household characteristics, caregiver's attitudes and knowledge, communication and information, and immunization services performance. A more in-depth analysis, covering all regions of the country, is necessary to support the determination of the main factors that lead to the failure in reaching the established goals.

\section{Table 2}

Immunization coverage according to sociodemographic aspects (education level, wealth quintile, and area of residence). Mozambique, from 1997 to 2015

\begin{tabular}{|c|c|c|c|c|c|c|c|c|c|c|}
\hline \multirow[t]{2}{*}{ Surveys } & \multicolumn{3}{|c|}{ Mother's education (\%) } & \multicolumn{5}{|c|}{ Wealth quintile (\%) } & \multicolumn{2}{|c|}{ Residence (\%) } \\
\hline & Illiterate & $\begin{array}{l}\text { Primary } \\
\text { School }\end{array}$ & $\begin{array}{c}\text { Secondary } \\
\text { School }\end{array}$ & Lowest & Second & Medium & Fourth & Highest & Rural & Urban \\
\hline 1997 & 30.6 & 54.3 & 89.7 & NA & NA & NA & NA & NA & 36.4 & 85.0 \\
\hline 2003 & 48.6 & 73.6 & 97.6 & 45.2 & 53.6 & 60.9 & 78.7 & 50.3 & 56.0 & 80.5 \\
\hline 2008 & 53.1 & 61.7 & 78.5 & 47.2 & 50.6 & 61.9 & 70.7 & 78.8 & 54.9 & 74.3 \\
\hline 2011 & 58.1 & 65.2 & 75.4 & 53.8 & 57.3 & 66.3 & 73.5 & 75.5 & 60.0 & 75.0 \\
\hline 2015 & 52.5 & 67.2 & 84.7 & 52.7 & 54.5 & 67.1 & 81.0 & 85.1 & 67.1 & 77.9 \\
\hline
\end{tabular}

NA: not applied. 


\section{Monitoring of the vaccine-preventable diseases}

The Mozambique Integrated Disease Surveillance and Response Handbook defines diseases as being required to report: polio (AFP), measles, rubella, neonatal tetanus, cholera, hemorrhagic fevers (Marburg, Ebola, rift valley, chikungunya, dengue) rotavirus, and pandemic influenza.

\section{- Polio}

One of the decade goals is to achieve a world free of poliomyelitis 2. In Mozambique, the last case of poliomyelitis caused by wild virus strain was reported in 1993. In 1997, the country established surveillance by laboratory diagnosis of samples with suspected cases of AFP. In 2006 the WHO issued a wild virus free country certification and the country has maintained this certification so far. Between 2011 and 2018 the country recorded a poliomyelitis event and outbreak in Zambézia province both derived from the vaccine strain. In 2018, two outbreaks of circulating vaccine-derived poliovirus type 2 virus were identified in Zambézia province in Molumbo district 53 . As strategy to block the circulation of poliovirus in Molumbo, in 2019 the Mozambican Ministry of Health in collaboration with several partners started mOPV2 massive immunization campaign. It is necessary to understand the causes of unimmunized children in outbreak areas to design strategies to reach them.

\section{- Measles and rubella}

The Mozambican National Institute of Health (INS) implemented surveillance for measles and rubella in 2006 following WHO recommendations 54. The suspected cases are notified by the Weekly Epidemiological Bulletin (WEB) and the case investigation are carried out with laboratory serology confirmation 55 .

Out of the 53,251 reported measles cases in Mozambique between 2003 and 2010 56, more than 25,000 were from 2003 alone, registered as one of the largest post-independence measles epidemics 55. Between 2006 and 2014, the proportion of children with confirmed rubella was $4.5 \%$ for children under 1 year and $13.1 \%$ for those aged between 1 and 4 years 54 . National campaigns were conducted throughout the country, in 2005 (from 9 months to 14 years old children), 2008 (from 9 to 59 months old), 2011 (from 6 to 59 months old) 54 and more recently in 2018 a combined measles and rubella campaign was conducted aiming to benefit more than 12 million children aged 6 months to 14 years 57 . However, cases continue to occur with 2,599 suspected cases and 29 confirmed results for 2018 (source: unpublished data of the INS). For many years, a single dose of measles vaccine was administered in children aged 9 months 58 but since 2015 a second dose is administered at 18 months old and more recently a combined measles-rubella (MR) vaccine was updated in the schedule. All these initiatives are expected to support the struggle against measles and rubella cases that the country has been reporting, especially in the areas that these diseases are recurrent.

\section{- Meningitis}

The pneumococcal conjugate 10-valent vaccine (PCV10) was introduced in the country in April 2013, using a 3-dose schedule without booster. The effect of this vaccine on the burden of pneumococcal meningitis was accessed by surveillance in children less than 5 years old in the three largest hospitals of Mozambique 59. The results showed a decrease in the cases of pneumococcal meningitis from $33.6 \%$ in 2013 to $1.9 \%$ in 2015 . A change in the pneumococcal serotype prevalence was observed after the introduction of PCV10 in Mozambique with the predominance of serotypes not covered by the vaccine 59. Thus, the National Expert Committee on Immunization in Mozambique (COPI) recommended a replacement from the PCV10 to PCV13 to cover more serotypes and a non-stop surveillance to monitor changes in the prevalence of the serotypes 24 . 


\section{- Rotavirus}

A surveillance system based on sentinel sites was implemented in 2014 by the INS. Rotarix vaccine was introduced in the EPI in September 2015. Data from the period before vaccine introduction showed that rotavirus prevalence was higher than $40 \% 60$ and that rotavirus was the principal agent attributed to diarrhea in children aged under five years 61 . As a result of the vaccine introduction, the frequency reduced to $13.5 \%$ in the second year post-vaccine 62 .

A recent analysis showed that due to several actions implemented in the country including vaccination against rotavirus, a significant reduction in the burden of diarrhea in Mozambique is observed 21 .

\section{EPI next steps and perspectives}

For the next years (2021-2025), Mozambique hopes to continue to receive the support of GAVI, for which has submitted a proposal focused on interventions in the provinces with the worst immunization performance.

Recognizing the main gaps in the system, three main objectives can be defined: (a) Ensure the vaccines availability in $98 \%$ at all levels, to achieve coverage. This includes the improvement of the cold chain and data management; (b) Improving the leadership and management based on knowledge, skills, evidence, and fully integrated coordination. This will include operational research for decision making on quality service delivery; (c) Provide good quality immunization, engagement with the community and effective communication to reduce the incidence of vaccine-preventable disease.

\section{Study limitations}

The lack of surveys in the period between 2016 and 2019, does not allow us to continually evaluate national and provincial coverage and vaccination trends in recent years. However, there are official data in this period. One of the big challenges is related to the differences among official reports and WHO/UNICEF estimates which can be explained by several reasons, one of them, the methodology of data collection. WHO/UNICEF's are based on community surveys, official data or/and other data available in the country using statistical and mathematics estimates. Whereas the official data are derived from Mozambique's administrative data or other sources reported by the country authorities. Although low data quality, registration book incompleteness, timelineless, issues with numerator and denominator which drives for covers up to $100 \%$ are implicated in official data, that is why in this article is focused on surveys and WHO/UNICEF data.

Another significant limitation is the methodology used for a narrative review which has a different approach for the selection of the used literature as it is done by convenience considering what is available regarding the topic when compared to systematic reviews.

There is no information on other factors that may be related to low coverage in Mozambique, other countries already carry out a secondary analysis of surveys to better understand the weaknesses and successes of their immunization programs. Robust analyzes must be carried out in Mozambique to understand which other determinants may be related to incomplete immunization status and figure how they can be improved.

\section{Final remarks and conclusions}

As far as we know, this is the first narrative review containing relevant information about the immunization program in Mozambique in post-independence. Through this process, 28 articles have been selected, from which one was related to financing; four were related to the EPI worldwide and the goals set; seven were related to coverage immunization determinants in African countries; 10 related to immunization in Mozambique, and six related to monitoring vaccine-preventable disease. 
The literature used during the analysis have shown a gap related to the identification of the main determinants to low immunization coverage in Mozambique, either nationally or locally. We found no information regarding how the lack of human resources, stock rupture of vaccines, natural disasters in the country have affected the performance of the EPI over time.

Forty years of EPI in Mozambique have shown significant improvements in the national immunization, characterized by the introduction of strategic vaccines, an overall increase in the national and provincial coverage, a decrease in the number of children that did not receive any of the basic vaccines, implementation of strategies to increase the immunization coverage and the establishment of monitoring system of the VPD as an important tool to detected outbreaks and to respond appropriately to these events.

However, national coverage remains below the WHO recommendation of $90 \%$. There are provinces (Zambézia, Nampula, and Tete) that have been continuously reporting low immunization coverage over the years and some, as Cabo Delgado with oscillating coverage.

It is necessary to understand the determinants of low coverage and also the factors related to dropouts of Polio vaccine in order to retain these cases, providing timely and full immunization. The constant outbreaks of cholera, polio, and measles that have been reported in the provinces previously mentioned is an equally relevant aspect. The aspects raised above, suggest the need for operational research, thus creating evidence that can guide decision-makers, also improving the immunization indicators in Mozambique.

One of the major findings of this manuscript is the fact that less than $25 \%$ of the budget of total immunization services is provided by the government. The other $75 \%$ of the budget is funded by external support such as GAVI, which have been reaching its goal, considering that coverage numbers are notably improving. However, some bottlenecks such as availability of human resources, vaccine stock rupture, geographical dispersion of some communities, may affect the effectiveness of the immunization service.

\section{Contributors}

M. Cassocera and N. Deus contributed to the conception, writing, and revision of the manuscript. A. Chissaque contributed to the writing and revision of the manuscript. M. R. O. Martins contributed to the review of the manuscript.

\section{Additional informations}

ORCID: Marta Cassocera (0000-0002-0019-1375); Assucênio Chissaque (0000-0002-9470-6068); Maria R. O. Martins (0000-0002-7941-0285); Nilsa de Deus (0000-0001-6769-7111).

\section{Acknowledgments}

We would like to thank the Calouste Gulbenkian Foundation and the Flandres Government (Building Institutional Capacity at the Mozambique INS - BICMINS) from where M. Cassocera has a PhD scholarship; Fundo Nacional de InvestigaçãoMoçambique and German Research Foundation (DFG) from where A. Chissaque has scholarship. Sousa Ribe and Orvalho Augusto for the inputs and clarifications regarding the Expanded Program on Immunization.

\section{Conflicts of interest}

The authors have no conflicts of interest to declare. 


\section{Reference}

1. World Health Organization; United Nations Children's Fund. Global immunization data. https://www.who.int/immunization/moni toring_surveillance/global_immunization_da ta.pdf (accessed on 25/Jul/2019).

2. World Health Organization. Global Vaccine Action Plan 2011-2020. https://www.who.int/ immunization/global_vaccine_action_plan/ GVAP_doc_2011_2020/en/ (accessed on 26/ Jun/2019).

3. Uwizihiwe JP, Bock H. 40th anniversary of introduction of Expanded Immunization Program (EPI): a literature review of introduction of new vaccines for routine childhood immunization in Sub-Saharan Africa. Int J Vaccines Vaccin 2015; 1:00004.

4. World Health Organization; United Nations Children's Fund. GIVS: Global Immunization Vision and Strategy 2006-2015. https://apps. who.int/iris/bitstream/handle/10665/69146/ WHO_IVB_05.05.pdf;jsessionid=624E13C6 1A22A378A9476FEECF747F92? sequence $=1$ (accessed on 22/Sep/2019).

5. Lopalco PL, Carrillo Santisteve P. Actual immunization coverage throughout Europe: are existing data sufficient? Clin Microbiol Infect 2014; 20 Suppl 5:7-11.

6. Centers for Disease Control and Prevention. VaxView. https://www.cdc.gov/vaccines/vax view/index.html (accessed on 05/May/2020).

7. De Figueiredo A, Were F. Local trends in immunisation coverage across Africa. Lancet 2019; 393:1779-81.

8. Feldstein LR. Global Routine Vaccination Coverage, 2016. MMWR Morb Mortal Wkly Rep 2017; 66:1252-5.

9. Instituto Nacional de Estatística. Moçambique: Inquérito Demográfico e de Saúde 1997. http://www.ine.gov.mz/operacoes-estatisti cas/inqueritos/inquerito-demografico-e-desaude/ids-1997.pdf/view (accessed on 13/ Aug/2019).

10. Instituto Nacional de Estatística; Ministério da Saúde. MEASURE DHS+/ORC Macro. Moçambique Inquérito Demográfico e de Saúde 2003. http://www.ine.gov.mz/operacoes-esta tisticas/inqueritos/inquerito-demografico-ede-saude/ids-2003.pdf/view (accessed on 13/ Aug/2019).

11. Instituto Nacional de Estatística; United Nations Children's Fund. Inquérito de Indicadores Múltiplos 2008. https://micssurveys-prod.s3.amazonaws.com/MICS3/ Eastern\%20and\%20Southern\%20Africa/ Mozambique/2008/Final/Mozambique\%20 2008\%20MICS_Portuguese.pdf (accessed on 13/Aug/2019).

12. Instituto Nacional de Estatística. Moçambique Inquérito Demográfico e de Saúde 2011. http://www.ine.gov.mz/operacoes-estatisti cas/inqueritos/inquerito-demografico-e-desaude/ids-2011.pdf/view (accessed on 13/ Aug/2019).
13. Ministério da Saúde; Instituto Nacional de Estatística. Inquérito de indicadores de imunização, malária e HIV/SIDA em Moçambique (IMASIDA) 2015. https://dhsprogram.com/ pubs/pdf/AIS12/AIS12_SP.pdf (accessed on 05/Oct/2020).

14. World Health Organziation. Immunization, vaccines and biologicals-immunization coverage. https://www.who.int/immunization/ monitoring_surveillance/routine/coverage/ en/ (accessed on 05/Aug/2020).

15. Ministry of Health. Expanded programme on immunization. Comprehensive MultiYear Plan (cMYP) 2007-2009. https://www. afro.who.int/sites/default/files/201706/Expanded\%20Programme\%20on\%20Immuniza tion\%20Comprehensive\%20Multi-Year\%20 Plan\%2C\%202007 2009\%20.pdf (accessed on 20/Jun/2019).

16. Ministry of Health. Comprehensive MultiYear Plan (cMYP) 2015-2019. https://extranet. who.int/countryplanningcycles/sites/default/ files/country_docs/Mozambique/mozam bique-_multi-year_plan_-_2015-2019_final_ august_2014.pdf (accessed on 20/Jun/2019).

17. Cutts F, Soares A, Jecque AV, Cliff J, Kortbeek $\mathrm{S}$, Colombo S. The use of evaluation to improve the Expanded Program on Immunization in Mozambique. Bull World Health Organ 1990; 68:199-208.

18. Direção Nacional de Saúde Pública, Ministério da Saúde. Manual do Programa Alargado de Vacinação. Maputo: Ministério da Saúde; 2014.

19. Shemwell SA, Peratikos MB, González-Calvo L, Renom-Llonch M, Boon A, Martinho S, et al. Determinants of full vaccination status in children aged 12-23 months in Gurùé and $\mathrm{Mi}$ lange districts, Mozambique: results of a population-based cross-sectional survey. Int Health 2017; 9:234-42,

20. Muloliwa AM, Cliff J, Oku A, Oyo-Ita A, Glenton $\mathrm{C}$, Ames $\mathrm{H}$, et al. Using the COMMVAC taxonomy to map vaccination communication interventions in Mozambique. Glob Health Action 2017; 10:1321313.

21. Chissaque A, Deus N, Vubil D, Mandomando I. The epidemiology of diarrhea in children under 5 years of age in Mozambique. Current Tropical Medicine Reports 2018; 5:115-24.

22. Maes K, Kalofonos I. Becoming and remaining community health workers: perspectives from Ethiopia and Mozambique. Soc Sci Med 2013; 87:52-9.

23. Ndima SD, Sidat M, Give C, Ormel H, Kok MC, Taegtmeyer M. Supervision of community health workers in Mozambique: a qualitative study of factors influencing motivation and programme implementation. Hum Resour Health 2015; 13:63. 
24. PATH. The GAVI full country evaluations evaluation-evaluation findings brief Mozambique. https://www.path.org/resources/ overview-of-gavi-full-country-evaluationsfindings/ (accessed on 08/Sep/2019).

25. GAVI Full Country Evaluations Team. GAVI Full Country Evaluations: 2016 Dissemination Report, Mozambique. https://www.gavi.org/ sites/default/files/document/2016-full-coun try-evaluations-report---mozambiquepdf.pdf (accessed on 25/Sep/2019).

26. Ikilezi G, Augusto OJ, Dieleman JL, Sherr K, Lim SS. Effect of donor funding for immunization from Gavi and other development assistance channels on vaccine coverage: evidence from 120 low and middle income recipient countries. Vaccine 2020; 38:588-96.

27. GAVI The Global Alliance for Vaccine and Immunizations. GAVI: The Vaccine Alliance. How our support works. https://www.gavi. org/programmes-impact/our-support (accessed on 18/May/2020).

28. GAVI The Global Alliance for Vaccine and Immunizations. GAVI support for Mozambique. https://www.gavi.org/programmes-impact/ country-hub/africa/mozambique (accessed on 20/Jul/2019).

29. Ministry of Health. Comprehensive MultiYear Plan (cMYP) 2012-2016. http://www. nationalplanningcycles.org/sites/default/files/ planning_cycle_repository/mozambique/mo zambique_cmyp_2012-2016_.pdf (accessed on 20/Jun/2019).

30. Atlas Mundial de Dados. Recursos humanos para a saúde cada a 1.000 habitantes. https:// pt.knoema.com/atlas/topics/Sa\%C3\%BAde/ Recursos-Humanos-para-a-sa\%C3\%BAdecada-1000-habitantes/Enfermagem-e-pes soal-de-obstetr\%C3\%ADcia (accessed on 30/ May/2020).

31. Organização Mundial da Saúde. Sara 2018 inventário nacional. https://www.afro.who.int/ pt/publications/sara-2018-inventario-nacio nal (accessed on 19/May/2020).

32. Jani JV, Jani IV, Araújo C, Sahay S, Barreto J, Bjuneet G. Assessment of routine surveillance data as a tool to investigate measles outbreaks in Mozambique. BMC Infect Dis 2006; 6:29.

33. Mavimbe JC, Braa J, Bjune G. Assessing immunization data quality from routine reports in Mozambique. BMC Public Health 2005; 5:108.

34. Instituto Nacional de Estatística; Ministério da Saúde; Ministério do Planeamento e do Desenvolvimento Territoria. Angola: inquérito de indicadores múltiplos e de saúde, 2015-2016. https://dhsprogram.com/pubs/pdf/FR327/ FR327.pdf (accessed on 13/Aug/2019).

35. National Department of Health; Statistics South Africa; South African Medical Research Council. South Africa Demographic and Health Survey 2016. https://dhsprogram.com/ pubs/pdf/FR337/FR337.pdf (accessed on 13/ Aug/2019).
36. Ministry of Health, Community Development, Gender, Elderly and Children; Ministry of Health; National Bureau of Statistics; Office of the Chief Government Statistician. Tanzania Demographic and Health Survey and malaria indicator survey (TDHS-MIS) 2015-16. https://dhsprogram.com/pubs/pdf/FR321/ FR321.pdf (accessed on 13/Aug/2019).

37. Zambia Statistics Agency, Ministry of Health. Zambia Demographic and Health Survey 2018. https://www.dhsprogram.com/pubs/pdf/ FR361/FR361.pdf (accessed on 13/Aug/2019).

38. Zimbabwe National Statistics Agency; ICF International. Zimbabwe Demographic and Health Survey 2015: final report. https:// dhsprogram.com/publications/publicationfr322-dhs-final-reports.cfm (accessed on 15/ May/2020).

39. Global Polio Eradication Initiative. Where we work. http://polioeradication.org/where-wework/ (accessed on 17/Sep/2019).

40. The Namibia Ministry of Health and Social Services; ICF International. The Namibia Demographic and Health Survey 2013. https:// dhsprogram.com/pubs/pdf/fr298/fr298.pdf (accessed on 15/May/2020).

41. Central Statistical Office; Macro International. Swaziland Demographic and Health Survey 2006-07. https://dhsprogram.com/pubs/pdf/ fr202/fr202.pdf (accessed on 15/May/2020).

42. Ministère du Plan et Suivi de la Mise en œuvre de la Révolution de la Modernité; Ministère de la Santé Publique; ICF Internationa. Enquête Démographique et de Santé en République Démocratique du Congo 2013-2014. https:// www.unicef.org/drcongo/media/1046/file/ EDS-RDC\%20II\%202013-2014.pdf (accessed on $15 /$ May/2020).

43. Institut National de la Statistique; ICF Macro. Enquête Démographique et de Santé de Madagascar 2008-2009. https://microdata.world bank.org/index.php/catalog/1435 (accessed on 15/May/2020).

44. Baguune B, Ndago JA, Adokiya MN. Immunization dropout rate and data quality among children 12-23 months of age in Ghana. Arch Public Health 2017; 75:18.

45. Wariri O, Edem B, Nkereuwem E, Nkereuwem OO, Umeh G, Clark E, et al. Tracking coverage, dropout and multidimensional equity gaps in immunisation systems in West Africa, 20002017. BMJ Glob Health 2019; 4:e01713.

46. Mozambique Country Card - 2019. https:// hi.org/sn_uploads/federation/country/pdf/ 2019_CountrySheet_Mozambique_Version Longue_EN_1.pdf (accessed on 23/Feb/2020).

47. Anokye R, Acheampong E, Budu-Ainooson A, Edusei AK, Okyere P, Dogbe J, et al. Socio-demographic determinants of childhood immunization incompletion in Koforidua, Ghana. BMC Res Notes 2018; 11:656. 
48. Russo G, Miglietta A, Pezzotti P, Biguioh RM, Mayaka GB, Sobzeet MS, al. Vaccine coverage and determinants of incomplete vaccination in children aged 12-23 months in Dschang, West Region, Cameroon: a cross-sectional survey during a polio outbreak. BMC Public Health 2015; 15:630.

49. Mbengue MAS, Sarr M, Faye A, Badiane O, Camara FBN, Mboup S, et al. Determinants of complete immunization among senegalese children aged 12-23 months: evidence from the demographic and health survey. BMC Public Health 2017; 17:630.

50. Legesse E, Dechasa W. An assessment of child immunization coverage and its determinants in Sinana District, Southeast Ethiopia. BMC Pediatr 2015; 15:31.

51. Jani JV, De Schacht C, Jani IV, Bjune G. Risk factors for incomplete vaccination and missed opportunity for immunization in rural Mozambique. BMC Public Health 2008; 8:161.

52. Marbán-Castro E, Sacoor C, Nhacolo A, Augusto O, Jamisse E, López-Varela E, et al. BCG vaccination in southern rural Mozambique: an overview of coverage and its determinants based on data from the demographic and health surveillance system in the district of Manhiça. BMC Pediatr 2018; 18:56.

53. Circulating vaccine-derived poliovirus type 2 - Mozambique. Disease outbreak news (25 January 2019). https://reliefweb.int/report/ mozambique/circulating-vaccine-derivedpoliovirus-type-2-mozambique-disease-outbreak-news-25 (accessed on 31/Aug/2019).

54. Amade NA, Sultane T, Augusto O, Ali S, Jani IV, Gudo ES. Seroepidemiology of rubella in Mozambique, 2006-2014: implications for rubella immunization in settings with high fertility rates. Pediatr Infect Dis J 2016; 35:1062-8.

55. Departamento de Epidemiologia, Direcção Nacional de Saúde Pública, Ministério da Saúde. Manual de vigilância epidemiológica do sarampo. Maputo: Ministério da Saúde; 2009.
56. Muloliwa AM, Camacho LAB, Verani JFS Simões TC, Dgedge MC. Impact of vaccination on the incidence of measles in Mozambique in the period 2000 to 2011. Cad Saúde Pública 2013; 29:257-69.

57. Organização Mundial da Saúde. Ministério da Saúde realiza Campanha de Vacinação contra Sarampo e Rubéola. https://www.afro.who. $\mathrm{int} / \mathrm{pt} / \mathrm{news} / \mathrm{ministerio-da-saude-realiza-}$ campanha-de-vacinacao-contra-sarampo-erubeola (accessed on 15/May/2020).

58. Mandomando I, Naniche D, Pasetti MF, Cuberos L, Sanz S, Vallès X, et al. Assessment of the epidemiology and burden of measles in Southern Mozambique. Am J Trop Med Hyg 2011; 85:146-51.

59. Sigaúque B, Moiane B, Massora S, Pimenta F, Verani JR, Mucavele H, et al. Early declines in vaccine type pneumococcal carriage in children less than 5 years old after introduction of 10 -valent pneumococcal conjugate vaccine in Mozambique. Pediatr Infect Dis J 2018; 37:1054-60.

60. Deus ND, Jo E, Cuamba A, Cassocera M, Luís L, Acácio S, et al. Epidemiology of rotavirus infection in children from a rural and urban area , in Maputo, Southern Mozambique, before Vaccine Introduction. Journal of Tropical Pediatrics 2017; 64:141-5.

61. Kotloff KL, Nataro JP, Blackwelder WC, Barlettaa VH, Carvalho IP, Rose TL, et al. Burden and aetiology of diarrhoeal disease in infants and young children in developing countries (the Global Enteric Multicenter Study, GEMS): a prospective, case-control study. Lancet 2013; 382:209-22.

62. de Deus N, Chilaúle JJ, Cassocera M, Bambo M, Langa JS, Sitoe E, et al. Early impact of rotavirus vaccination in children less than five years of age in Mozambique. Vaccine 2018 36:7205-9. 


\section{Resumo}

Em Moçambique, o Programa Alargado de Vacinação (PAV) foi implementado em 1979 com o compromisso de reduzir a morbimortalidade na população infantil através dos serviços de imunização. O presente estudo tem como objetivo descrever as características do PAV e revisar as informações disponíveis relacionadas aos serviços de imunização em Moçambique, os avanços e perspectivas. Foi realizada uma revisão narrativa da literatura, e as bases de dados acessadas foram BVS, Google Scholar e PubMed, entre 1979 e 2019, usando descritores relacionados ao tema. A revisão acessou um total de 28 artigos científicos, além de outras fontes relevantes. A cobertura nacional de vacinação em Moçambique entre 1997 (47\%) e 2015 (66\%) aumentou 19 pontos percentuais, e a cobertura de vacinação em crianças abaixo de 12 meses de idade aumentou de 44,3\% (1997) para 57\% (2015). De acordo com os dados de 2015, das 11 províncias, apenas as do Sul e a de Cabo Delgado atingiram a meta de cobertura recomendada de $80 \%$. As províncias de Zambézia, Nampula e Tete mostraram baixas coberturas ao longo dos anos, enquanto Cabo Delgado mostrou oscilação na cobertura. As vacinas BCG, DPT3, Polio $3 e$ sarampo atingiram a meta de cobertura de $80 \%$ entre 1997 e 2015. Nossa análise mostrou avanços importantes na vacinação nacional, caracterizados por um aumento geral nas coberturas nacional e provinciais e uma queda no número de crianças que não receberam nenhuma vacina. Apesar desses avanços, algumas províncias tiveram coberturas aquém das metas, o que reforça a necessidade de entender os determinantes do abandono da imunização nas crianças, para retê-las e assegurar a imunização oportuna e completa.

Criança; Cobertura Vacinal; Inquéritos

\section{Resumen}

En Mozambique, el Programa de Inmunización Expandido (EPI por sus siglas en inglés) fue implementado en 1979, con el compromiso de reducir la mortalidad infantil y la morbilidad a través de la provisión de servicios de inmunización. El objetivo del presente estudio es describir las características del EPI y revisar la información disponible, relacionada con el servicio de inmunización en Mozambique, así como sus logros y perspectivas. Se llevó a cabo una revisión narrativa de la literatura y se accedió a las siguientes bases de datos electrónicas: BVS, Google Scholar y PubMed para el período de 1979 a 2019, usando descriptores relacionados con el tema. Se tuvo acceso a un total de 28 artículos y otras fuentes relevantes para la revisión. La cobertura nacional de inmunización en Mozambique de 1997 (47\%) a 2015 (66\%) mejoró 19 puntos porcentuales y la cobertura de inmunización de los niños con menos de 12 meses se incrementó de un 44,3\% (1997) a un 57\% (2015). La encuesta de 2015 mostró que, de las 11 provincias, solamente la provincia del sur y la provincia de Cabo Delgado podrían alcanzar el $80 \%$ de la meta recomendada a nivel provincial. Las provincias de Zambézia, Nampula, y Tete han estado informando de baja cobertura a largo de estos años y Cabo Delgado tiene oscilaciones en la cobertura. BCG, DPT3, Polio 3 y sarampión han alcanzado un 80\% de la meta de la cobertura de 1997-2015. Nuestro análisis ha mostrado importantes mejoras en la inmunización nacional, caracterizada por un aumento en general en la cobertura nacional $y$ provincial, así como un decremento en el número de niños que no recibieron ninguna vacuna. A pesar de estas mejoras, algunas provincias tienen coberturas más bajas que las esperadas y existe una necesidad para entender los determinantes del abandono en niños para retenerlos y proporcionarles a tiempo una completa inmunización.

Niño; Cobertura de Vacunación; Encuestas
Submitted on 03/Mar/2020

Final version resubmitted on 19/Jun/2020

Approved on 31/Jul/2020 